\title{
The Occurrence, Pathways, and Risk Assessment of Heavy Metals in Raw Milk from Industrial Areas in China
}

\author{
Chuanyou Su ${ }^{1,2,+}$, Yanan Gao ${ }^{1,+}$, Xueyin Qu ${ }^{3}$, Xuewei Zhou ${ }^{1}$, Xue Yang ${ }^{1}$, Shengnan Huang ${ }^{1}$, Lei Han ${ }^{1}$, \\ Nan Zheng ${ }^{1, *}$ and Jiaqi Wang ${ }^{1, *}$
}

1 Milk and Dairy Product Inspection Center of Ministry of Agriculture and Rural Affairs, Institute of Animal Sciences, Chinese Academy of Agricultural Sciences, Beijing 100193, China; suchuanyou2010@hotmail.com (C.S.); gaoyanan2019@gmail.com (Y.G.); zhouxuewei@gdou.edu.cn (X.Z.); 82101182216@caas.cn (X.Y.); hsn1435007@hotmail.com (S.H.); lhan25122@gmail.com (L.H.)

2 College of Animal Science and Technology, Henan Agriculture University, Zhengzhou 450046, China

3 Tianjin Mengde Group Co., Ltd., Tianjin 300400, China; quxueyin@hotmail.com

* Correspondence: zhengnan@caas.cn (N.Z.); wangjiaqi@caas.cn (J.W.); Tel.: +86-10-62816069 (N.Z. \& J.W.)

+ These authors contributed equally to the work.

Citation: Su, C.; Gao, Y.; Qu, X.; Zhou, X.; Yang, X.; Huang, S.; Han, L.; Zheng, N.; Wang, J. The Occurrence, Pathways, and Risk Assessment of Heavy Metals in Raw Milk from Industrial Areas in China. Toxics 2021, 9, 320. https://doi.org/10.3390/ toxics 9120320

Academic Editor: Claudio Medana

Received: 26 October 2021

Accepted: 22 November 2021

Published: 26 November 2021

Publisher's Note: MDPI stays neutral with regard to jurisdictional claims in published maps and institutional affiliations.

Copyright: (c) 2021 by the authors. Licensee MDPI, Basel, Switzerland. This article is an open access article distributed under the terms and conditions of the Creative Commons Attribution (CC BY) license (https:// creativecommons.org/licenses/by/ $4.0 /)$.

\begin{abstract}
This study evaluated chromium (Cr), arsenic (As), cadmium (Cd), and lead (Pb) contamination in raw milk from industrial areas in China, identified the possible pathways of heavy metals from the environment to raw milk, and made a risk assessment of the consumption of heavy metals from milk consumption. The $\mathrm{Cr}, \mathrm{As}, \mathrm{Cd}$, and $\mathrm{Pb}$ concentrations in raw milk, water and silage were analyzed using inductively coupled plasma mass spectrometry. The $\mathrm{Cr}$ and As in soil were analyzed by flame atomic absorption spectrometry and atomic fluorescence spectrometry, respectively. Cd and $\mathrm{Pb}$ in soil were determined by a Graphite furnace atomic absorption spectrophotometer. The $\mathrm{Cr}$ and As concentrations in milk from industrial areas were $2.41 \pm 2.12$ and $0.44 \pm 0.31 \mu \mathrm{g} / \mathrm{kg}$, respectively, which were significantly higher $(p<0.01)$ than those from non-industrial areas, which had levels of $1.10 \pm 0.15$ and $0.25 \pm 0.09 \mu \mathrm{g} / \mathrm{kg}$, respectively. Chromium was mainly transferred through the soil-silage-milk pathway, As was transferred through the water-silage-milk pathway, while Cd was mainly transferred through the soil (water)-silage-milk pathway. The contributions of each metal to the overall hazard index $(\mathrm{HI})$ followed a descending order of $\mathrm{As}, \mathrm{Cr}, \mathrm{Pb}$, and $\mathrm{Cd}$, with values of $46.64 \%, 25.54 \%, 24.30 \%$, and $3.52 \%$, respectively. Children were at higher risk than adults.
\end{abstract}

Keywords: heavy metals; raw milk; industrial; risk assessment; China

\section{Introduction}

With increasing population, industrialization, and urbanization, various pollutants have been released into the environment. Some heavy metals have become widely distributed in the environment, in particular, chromium $(\mathrm{Cr})$, arsenic (As), cadmium (Cd), and lead $(\mathrm{Pb})$ [1], facilitating their entry in the human food chain [2]. Heavy metals have negative effects on both livestock health [3,4] and human health [5]. These metals are potentially toxic, causing hematologic, neurotoxic, and nephrotoxic effects even at low concentrations. Human exposure to these heavy metals has a negative effect on specific organs and may lead to metabolic disorders, fatigue, heart failure, and cancer $[4,6-8]$. This problem is particularly serious for children, whose immune systems are underdeveloped and for whom gastrointestinal absorption is not as efficient as in adults [9]. Hexavalent chromium ( $\mathrm{Cr} \mathrm{VI}$ ), As, and $\mathrm{Cd}$ are group 1 carcinogens, while inorganic $\mathrm{Pb}$ is a group $2 \mathrm{~A}$ carcinogen, as classified by the International Agency for Research on Cancer (IARC) [10]. In the United States, according to their occurrence, toxicity, and potential human exposure, $\mathrm{As}, \mathrm{Pb}, \mathrm{Cd}$, and $\mathrm{Cr}$ were listed as the $1 \mathrm{st}, 2 \mathrm{nd}, 7 \mathrm{th}$, and 17 th priority contaminants in food by the Agency for Toxic Substances and Disease Registry (ATSDR) [11]. The levels of these heavy metals in milk can not only be used as a direct indicator of milk hygiene, 
but also as an indirect indicator of environmental pollution in the areas where raw milk is produced $[1,12,13]$. Thus, the monitoring of heavy metals in milk is vital for product quality and must be regarded as an essential public health procedure. In China, to protect human health, the government has set maximum level (ML) standards for $\mathrm{Cr}$, $\mathrm{As}$, and $\mathrm{Pb}$ in raw milk of $0.3,0.1$, and $0.05 \mathrm{mg} / \mathrm{kg}$, respectively [14].

Sources of heavy metal pollution include mining, the proximity of roads, fuel combustion, and industrial areas, especially iron and steel plants [15]. In some areas, the concentrations of heavy metals in raw milk vary due to the differences in pollution levels $[16,17]$. Some researchers have focused on the assessment of potential health risks for residents in contaminated areas, including areas irrigated with wastewater [18] and areas in the vicinity of the petroleum extraction industry [4]. In China, only a few studies have attempted to assess the levels of heavy metals in milk, especially milk from cows reared in industrial areas. In our previous study, we conducted a risk assessment of heavy metals in raw milk from a variety of milk producing areas [19] and areas close to leatherprocessing plants [9]. However, few studies have assessed the risk of heavy metals to people (from infants to seniors) in areas with industrial sites such as cement production and power plants.

We hypothesized that $\mathrm{Cr}, \mathrm{As}, \mathrm{Cd}$, and $\mathrm{Pb}$ levels in locally produced milk would be elevated if the levels were high in the local water, soil, and silage due to industrial activity. The aims of the study were to: (i) compare the heavy metal concentrations in raw milk from industrial and non-industrial areas in China; (ii) identify the relationships among heavy metals in raw milk, silage, water, and soil, and the possible pathways of heavy metals from the environment to raw milk; and (iii) evaluate the heavy metal exposure and health risks from milk consumption for local residents.

\section{Materials and Methods}

\subsection{Study Area}

During autumn 2019, samples were collected from 20 farms in Tangshan (5), Tianjin (7), Hohhot (6), Weifang (1), and Qiqihar (1) in China. Tangshan $\left(117^{\circ} 31^{\prime}-119^{\circ} 19^{\prime} \mathrm{E}\right.$, $38^{\circ} 55^{\prime}-40^{\circ} 28^{\prime} \mathrm{N}$; 7.72 million people) and Hohhot $\left(110^{\circ} 46^{\prime}-112^{\circ} 10^{\prime} \mathrm{E}, 40^{\circ} 51^{\prime}-41^{\circ} 8^{\prime} \mathrm{N}\right.$; 3.45 million people) are industrialized cities with factories, including steel plants, cement plants, and waste incineration plants, which are all potential sources of environmental contamination. Tianjin $\left(116^{\circ} 43^{\prime}-118^{\circ} 4^{\prime} \mathrm{E}, 38^{\circ} 34^{\prime}-40^{\circ} 15^{\prime} \mathrm{N}\right.$; 13.87 million people) is also a mega-city with many steel plants, cement plants, and a waste incineration plant. The farms selected industrial area were withen $30 \mathrm{~km}$ from the cement plants or waste incineration plant. Weifang $\left(118^{\circ} 10^{\prime}-120^{\circ} 01^{\prime}\right.$ E, $35^{\circ} 41^{\prime}-37^{\circ} 26^{\prime} \mathrm{N}$; 9.91 million people) and Qiqihar $\left(122^{\circ} 24^{\prime}-126^{\circ} 41^{\prime}\right.$ E, $46^{\circ} 13^{\prime}-48^{\circ} 56^{\prime} \mathrm{N}$; 5.59 million people) are cities located in agricultural areas and are close to a wetland reserve. Weifang and Qiqihar were therefore expected to be free from contamination and were considered to represent a control area.

\subsection{Sampling}

Raw milk was sampled from each farm from five lactating Holstein cows in their 3rd parity. A total of 100 milk samples were collected in polyethylene plastic bottles from 20 farms. Silage (1), drinking water (1), and soil samples (1) were also collected from each farm. Silage samples were randomly collected from the lower, middle, and upper parts of silos. Soil samples were taken from depths of $0-30 \mathrm{~cm}$ at six random points. Silage and soil samples were stored in polythene bags. The cows' drinking water (groundwater) was sampled and stored in $200 \mathrm{~mL}$ plastic bottles. After being gathered, all the samples were stored at $-20{ }^{\circ} \mathrm{C}$.

\subsection{Sample Preparation and Metal Analysis}

Silage samples were dried in an oven at $65{ }^{\circ} \mathrm{C}$ and ground to a particle size of $1 \mathrm{~mm}$. Raw milk $(1 \mathrm{~g})$ or silage $(0.5 \mathrm{~g})$ were added to a digestion vessel. Then, $5 \mathrm{~mL} 65 \% \mathrm{HNO}_{3}$ (Suprapur, Merck, Darmstadt, Germany) was added, followed by $2 \mathrm{~mL}$ of $30 \% \mathrm{H}_{2} \mathrm{O}_{2}$ 
(Suprapur ${ }^{\circledR}$, Merck, Kenilworth, NJ, USA). After a $12 \mathrm{~h}$ predigestion, the mixture was digested by a microwave assisted reaction system (CEM Corporation, Matthews, NC, USA), according to a program reported by Zhou et al. (2017) [20]. Following digestion and cooling to room temperature, the digestate was diluted to $50 \mathrm{~mL}$ with ultrapure water. The liquid samples were analyzed by inductively coupled plasma mass spectrometry (ICP-MS) (Agilent 7700 Series ICP-MS, Agilent Technologies, Santa Clara, CA, USA). Water samples mixed with $\mathrm{HNO}_{3}(1 \% v / v)$ were also analyzed by ICP-MS.

The pretreatment and analysis of soil samples was conducted according to the method described by Zhou et al. (2019) [15]. Briefly, the samples were naturally air-dried and then ground in the laboratory. The $\mathrm{Cr}$ level in soil was measured by flame atomic absorption spectrometry (ICE 3500, Thermo Fisher Scientific, Waltham, MA, USA), and Cd and Pb levels were measured using a graphite furnace atomic absorption spectrophotometer (Z-2700, Hitachi, Tokyo, Japan) after digestion with $\mathrm{HNO}_{3}, \mathrm{HCl}, \mathrm{HClO}_{4}$, and HF. The levels of As in soil were determined by atomic fluorescence spectrometry (AFS 9800, Beijing Kechuang Haiguang Instrument Company, Beijing, China) after digestion with $\mathrm{HCl}$ and $\mathrm{HNO}_{3}$.

The limits of detection (LODs) of $\mathrm{Cr}$, $\mathrm{As}, \mathrm{Cd}$, and $\mathrm{Pb}$ in milk were $0.82,0.028,0.03$, and $0.03 \mu \mathrm{g} / \mathrm{kg}$, respectively. The LODs of $\mathrm{Cr}, \mathrm{As}, \mathrm{Cd}$, and $\mathrm{Pb}$ in water and silage were, 0.130 , $1.500,0.003$, and $0.015 \mu \mathrm{g} / \mathrm{L}$ and $0.04,0.03,0.40$, and $2.40 \mu \mathrm{g} / \mathrm{kg}$, respectively. The LODs of $\mathrm{Cd}$, As, $\mathrm{Cr}$, and $\mathrm{Pb}$ in soil were $0.01,0.02,5$, and $0.1 \mathrm{mg} / \mathrm{kg}$, respectively. Values of heavy metals which under the LOD were calculated by a constant value of half the LOD [17].

\subsection{Risk Assessment}

\subsubsection{Exposure Assessment}

An exposure assessment was conducted for local residents (aged 3 to 69 years) using the mean $\mathrm{Cr}, \mathrm{As}, \mathrm{Cd}$, and $\mathrm{Pb}$ levels in milk from the industrial areas and the corresponding recommended milk consumption rates [21] and bodyweight [22]. The metal exposure from milk consumption was determined as follows [23]:

$$
\mathrm{EDI}=\mathrm{C} \times \mathrm{DI} / \mathrm{BW},
$$

where EDI is the estimated daily intake, BW is the body weight $(\mathrm{kg}), \mathrm{C}$ is the milk heavy metal concentration $(\mu \mathrm{g} / \mathrm{kg})$, and DI is the daily milk intake $(\mathrm{kg})$.

\subsubsection{Target Hazard Quotient (THQ)}

The non-carcinogenic risk potential chronic risk of heavy metals was expressed as the THQ and as a hazard index (HI). It was calculated as follows:

$$
\mathrm{THQ}=\mathrm{EDI} / \mathrm{RfD},
$$

where RfD is the oral reference dose, with values of $3 \times 10^{-3}, 3 \times 10^{-4}, 1 \times 10^{-3}$, and $4 \times 10^{-3} \mathrm{mg} / \mathrm{kg} / \mathrm{d}$ for $\mathrm{Cr}$, As, $\mathrm{Cd}$, and $\mathrm{Pb}$, respectively [24-28].

\subsubsection{Hazard Index}

The HI was used to assess the chronic risk from multiple heavy metals. It was calculated according to Equation (3). There was no risk to human health if $\mathrm{HI}<1[18,29]$.

$$
\mathrm{HI}=\sum \mathrm{THQ},
$$

\subsection{Data Analysis}

The data were analyzed with SPSS (IBM, Endicott, NY, USA) version 20. Results were expressed as a mean \pm standard deviation (SD). As the data were non-normal distribution, heavy metal contents in raw milk from non-industrial and industrial areas were compared using non-parametric Kruskal-Wallis tests. Differences were considered to be statistically 
significant at $p<0.05$. To explore these relationships, a Spearman's correlation analysis of the relationships among heavy metals in milk and silage, water, and soil was conducted.

\section{Results and Discussion}

\subsection{Levels of $\mathrm{Cr}, \mathrm{As}, \mathrm{Cd}$, and $\mathrm{Pb}$ in Raw Milk}

Concerns regarding the effects of heavy metals on human health have arisen due to their accumulation in the environment, particularly in livestock and agricultural production, increasing their potential to leave residue in human food [4]. Heavy metal exposure is positively related to the development of various diseases. Data collection and continuous monitoring are required to fully evaluate the impacts of heavy metals in food on human health in future studies [16]. As one potential source of heavy metals in the human diet, the monitoring of milk is therefore considered necessary [30]. In this study, we evaluated the heavy metal concentrations in raw milk from industrial and non-industrial areas in China (Table 1 and Figure 1). The ranges of the $\mathrm{Cr}, \mathrm{As}, \mathrm{Cd}$, and $\mathrm{Pb}$ levels in milk were $0.54-10.61,0.10-1.49,0.02-0.39$, and ND-15.22 $\mu \mathrm{g} / \mathrm{kg}$, respectively. The $\mathrm{Cr}$, As, and $\mathrm{Pb}$ concentrations were below the maximum levels (MLs) set in China of 300,100, and $50 \mu \mathrm{g} / \mathrm{kg}$, respectively [14]. The $\mathrm{Cd}$ concentration was below the limit of the Codex Alimentarius Commission (CAC) $(20 \mu \mathrm{g} / \mathrm{kg})$ [31]. The highest $\mathrm{Cr}$, As, and $\mathrm{Cd}$ concentrations in raw milk samples were observed in Hohhot. The highest $\mathrm{Pb}$ concentration in raw milk was observed in Tianjin, which was located in an industrial area.

The $\mathrm{Cr}$ and As levels in milk from industrial areas were $2.41 \pm 2.12$ and $0.44 \pm 0.31 \mu \mathrm{g} / \mathrm{kg}$, respectively, which were significantly higher $(p<0.01)$ than those from non-industrial areas, in which the levels were $1.10 \pm 0.15$ and $0.25 \pm 0.09 \mu \mathrm{g} / \mathrm{kg}$, respectively (Figure 1). Previous studies have shown that industrial activity can lead to high heavy metal levels in milk $[4,13]$. One previous study reported that levels of $\mathrm{As}$ and $\mathrm{Pb}$ in milk from cows reared in regions with a high traffic intensity and industrial activity were significantly $(p<0.05)$ higher than those from a rural area [32].

Table 1. The levels of heavy metals $(\mu \mathrm{g} / \mathrm{kg})$ in raw milk from five areas in China $(n=100)$.

\begin{tabular}{|c|c|c|c|c|c|c|c|}
\hline Area & & $\mathbf{N}$ & & $\mathrm{Cr}$ & As & $\mathrm{Cd}$ & $\mathbf{P b}$ \\
\hline \multirow{4}{*}{ Non-industrial } & \multirow{2}{*}{ I } & \multirow{2}{*}{5} & Mean \pm SD & $1.17 \pm 0.15^{b c}$ & $0.33 \pm 0.03^{c}$ & $0.05 \pm 0.02^{c}$ & $0.45 \pm 0.07^{b}$ \\
\hline & & & Range & $1.06-1.37$ & $0.31-0.38$ & $0.04-0.09$ & $0.40-0.56$ \\
\hline & \multirow{2}{*}{ II } & \multirow{2}{*}{5} & Mean \pm SD & $1.04 \pm 0.15^{c}$ & $0.17 \pm 0.02^{b}$ & $0.11 \pm 0.04^{\mathrm{ab}}$ & $0.94 \pm 0.19^{b}$ \\
\hline & & & Range & $0.87-1.28$ & $0.13-0.19$ & $0.04-0.15$ & $0.74-1.18$ \\
\hline \multirow{6}{*}{ Industrial } & \multirow{2}{*}{ III } & \multirow{2}{*}{25} & Mean \pm SD & $1.18 \pm 0.22^{c}$ & $0.24 \pm 0.09 \mathrm{bc}$ & $0.13 \pm 0.09^{\mathrm{a}}$ & $4.46 \pm 2.45^{\mathrm{a}}$ \\
\hline & & & Range & $0.90-1.89$ & $0.12-0.53$ & $0.04-0.41$ & $2.26-12.68$ \\
\hline & \multirow{2}{*}{ IV } & \multirow{2}{*}{35} & Mean \pm SD & $1.86 \pm 1.24^{b}$ & $0.42 \pm 0.24^{\mathrm{a}}$ & $0.11 \pm 0.06^{\mathrm{a}}$ & $2.68 \pm 3.60^{b}$ \\
\hline & & & Range & $0.54-7.03$ & $0.16-1.47$ & $0.02-0.31$ & ND-15.22 \\
\hline & \multirow{2}{*}{$\mathrm{V}$} & \multirow{2}{*}{30} & Mean \pm SD & $4.09 \pm 2.72^{\mathrm{a}}$ & $0.64 \pm 0.38^{a}$ & $0.09 \pm 0.08^{b c}$ & $2.29 \pm 3.10^{b}$ \\
\hline & & & Range & $0.87-10.61$ & $0.10-1.49$ & $0.02-0.39$ & ND-10.12 \\
\hline \multirow{2}{*}{ Total } & & \multirow{2}{*}{100} & Mean \pm SD & $2.28 \pm 2.01$ & $0.42 \pm 0.40$ & $0.10 \pm 0.07$ & $2.18 \pm 3.16$ \\
\hline & & & Range & $0.54-10.61$ & $0.10-1.49$ & $0.02-0.39$ & ND-15.22 \\
\hline \multicolumn{3}{|c|}{ Maximum level } & & 300 & 100 & 20 & 50 \\
\hline
\end{tabular}

Note: N represents the number of samples; I, II, III, IV, and V represent the areas of Qiqihar, Weifang, Tangshan, Tianjin, and Hohhot, respectively; Superscript lower-case letters $(\mathrm{a}, \mathrm{b}, \mathrm{c})$ different in the same column indicate significant differences $(p<0.05)$.

The heavy metal concentrations in raw milk reported by previous studies are summarized in Table 2. The milk Cr levels $(0.54-10.61 \mu \mathrm{g} / \mathrm{kg}$ ) measured in this study were consistent with levels reported elsewhere in China [15], as well as in Romania [33] and Spain [34], but were lower than the $\mathrm{Cr}$ concentrations reported in Bangladesh [35], Pakistan [29], and Turkey [36]. The range of As levels (0.10-1.49 $\mu \mathrm{g} / \mathrm{kg})$ in raw milk were consistent with the ranges observed in Korea [28], Romania [33], and elsewhere in China [15,17]. The As levels in this study were lower than the concentrations reported in Mexico [37] and Turkey [36,38]. The Cd concentrations in milk $(0.02-0.39 \mu \mathrm{g} / \mathrm{kg})$ measured in this study were consistent with levels previously reported in China [15,17], northeast Iran [39], western Iran [40], and 
Spain [34], but were lower than the Cd concentrations reported in Egypt [41], Pakistan [29], and Peru [42]. The Pb concentrations in milk $(0-15.22 \mu \mathrm{g} / \mathrm{kg})$ measured in this study were consistent with levels reported elsewhere in China [15,17], as well as in Iran [43], Korea [28], northeast Iran [39], Pakistan [44], Romania [33], and Spain [34], but were lower than those reported in Egypt [41], Peru [42], Turkey [32,36], and western Iran [40].

Table 2. Heavy metal concentrations in raw milk reported from different countries $(\mu \mathrm{g} / \mathrm{kg})$.

\begin{tabular}{|c|c|c|c|c|c|c|c|}
\hline Country & Year & $\mathbf{N}$ & $\mathrm{Cr}$ & As & $\mathrm{Cd}$ & $\mathrm{Pb}$ & Reference \\
\hline Argentina & - & 52 & - & - & $\begin{array}{l}1.47 \\
(0-17.0)\end{array}$ & - & [45] \\
\hline Bangladesh & 2014-2015 & 30 & $\begin{array}{l}373 \pm 8 \\
\text { (BDL-1233) }\end{array}$ & - & $\begin{array}{l}24 \pm 9 \\
\text { (BDL-73) }\end{array}$ & $\begin{array}{l}33 \pm 6 \\
(B D L-200)\end{array}$ & [35] \\
\hline Croatia & 2010-2014 & 249 & - & - & - & $\begin{array}{l}11.4 \pm 8.08 \\
(5.11-131)\end{array}$ & [46] \\
\hline China & 2016 & 997 & - & $\begin{array}{l}0.31 \pm 1.02 \\
(0.05-15.77)\end{array}$ & $\begin{array}{l}0.05 \pm 0.07 \\
(0.001-0.69)\end{array}$ & $\begin{array}{l}1.75 \pm 3.73 \\
(0.14-38.61)\end{array}$ & [17] \\
\hline China & 2017 & 60 & $\begin{array}{l}0.87 \pm 1.02 \\
(0.02-5.01)\end{array}$ & $\begin{array}{l}0.06 \pm 0.20 \\
(0.0002-1.53)\end{array}$ & $\begin{array}{l}0.09 \pm 0.006 \\
(0.01-0.27)\end{array}$ & $\begin{array}{l}1.22 \pm 1.62 \\
(0.03-10.46)\end{array}$ & [15] \\
\hline Egypt & - & 20 & - & - & $51 \pm 5$ & $214 \pm 21$ & [41] \\
\hline Iran & 2014 & 32 & - & $15.2-25.9$ & - & - & [47] \\
\hline Iran & - & 118 & - & - & $\begin{array}{l}3.47 \\
\text { (ND-100) }\end{array}$ & $\begin{array}{l}38.42 \\
\text { (ND-250) }\end{array}$ & [4] \\
\hline $\begin{array}{l}\text { North-east } \\
\text { Iran }\end{array}$ & - & 720 & - & - & $0.3 \pm 0.3$ & $12.9 \pm 6.1$ & [39] \\
\hline Western Iran & 2014 & 36 & - & - & $\begin{array}{l}0.036 \pm 0.28 \\
(0.06-0.78)\end{array}$ & $\begin{array}{l}32.8 \pm 20.80 \\
(15.7-68)\end{array}$ & [40] \\
\hline Korea & 2012 & 33 & - & $1.90 \pm 0.068$ & $2.38 \pm 0.023$ & $(3.35 \pm 0.076)$ & [28] \\
\hline Mexico & - & 60 & $30 \pm 10$ & $120 \pm 80$ & - & $30 \pm 10$ & [37] \\
\hline Pakistan & 2014 & 480 & - & - & 1 & 14 & [44] \\
\hline Pakistan & 2010-2011 & 30 & $\begin{array}{l}251.7 \pm 32 \\
(190-303)\end{array}$ & - & $\begin{array}{l}20 \pm 4 \\
(14-31)\end{array}$ & - & [29] \\
\hline Peru & 2018 & 20 & - & - & $\begin{array}{l}19.7 \pm 7.3 \\
(11.0-32.0)\end{array}$ & $\begin{array}{l}580 \pm 18 \\
(540-600)\end{array}$ & [42] \\
\hline Romania & - & - & 4.56 & 1.02 & 1.09 & 6.57 & [33] \\
\hline Spain & - & 347 & $\begin{array}{l}4.03 \pm 3.43 \\
(<\text { LOD- } \\
24.35)\end{array}$ & - & $\begin{array}{l}0.40 \pm 0.28 \\
(<\mathrm{LOD}-1.73)\end{array}$ & $\begin{array}{l}2.85 \pm 1.091 \\
(0.55-18.7)\end{array}$ & [34] \\
\hline Turkey & - & 20 & $(70-1227)$ & $(103-3326)$ & $(0.1-4)$ & $(25-124)$ & [36] \\
\hline Turkey & - & 20 & - & - & - & $\begin{array}{l}40.5 \\
(23-58)\end{array}$ & [32] \\
\hline Turkey & 2015-2016 & 112 & - & $\begin{array}{l}17.5 \pm 1.7 \\
(\mathrm{ND}-42.8)\end{array}$ & - & - & [38] \\
\hline China & 2019 & 120 & $(0.54-10.61)$ & $(0.10-1.49)$ & $(0.02-0.39)$ & (ND-15.22) & This study \\
\hline
\end{tabular}

Note: - Not mentioned in the reference.

\subsection{Levels of $\mathrm{Cr}, \mathrm{As}, \mathrm{Cd}$, and $\mathrm{Pb}$ in Silage, Water, and Soil}

Anthropogenic activities, especially industrial activities, will increase heavy metal accumulation in the environment. In industrial areas, heavy metal pollution in silage is usually more severe, resulting in elevated levels in blood, which are then excreted into milk [48]. For animals, polluted drinking water is also considered to be an important source of heavy metal exposure [49]. Therefore, silage and water have been monitored to estimate the source of heavy metal contamination $[29,50]$. Heavy metal levels in silage, water, and soil from industrial and non-industrial areas were shown in Table 3. The $\mathrm{Cr}, \mathrm{As}, \mathrm{Cd}$, and $\mathrm{Pb}$ concentrations in silage from industrial and non-industrial areas were in the ranges of $1.57-4.84,0.06-0.29,0.01-0.09$, and $0.26-1.17 \mathrm{mg} / \mathrm{kg}$ and $1.05-1.660 .05-0.110 .02-0.03$, and $0.16-0.22 \mathrm{mg} / \mathrm{kg}$, respectively. The ranges of $\mathrm{Cr}, \mathrm{As}, \mathrm{Cd}$, and $\mathrm{Pb}$ concentrations in water from industrial and non-industrial areas were ND-4.93, 0.15-2.80, ND-0.040, and $0.01-0.10 \mu \mathrm{g} / \mathrm{L}$ and $0.07-0.38,0.30-0.47,0.001-0.005$, and $0.09-0.15 \mu \mathrm{g} / \mathrm{L}$, respectively. 
The ranges of the four heavy metals in soil from industrial and non-industrial areas were 42-218, 3.73-17.30, 0.06-0.27, and 21-42 mg/ kg, and 59-133, 5.48-10.20, 0.09-0.10, and 24-29 mg/kg, respectively. Silage $\mathrm{Cr}$, As, $\mathrm{Cd}$, and $\mathrm{Pb}$ levels were below the Chinese MLs (5, 2, 1, and $30 \mathrm{mg} / \mathrm{kg}$, respectively) [51]. The $\mathrm{Cr}, \mathrm{As}, \mathrm{Cd}$, and $\mathrm{Pb}$ concentrations in water and soil were lower than the MLs for drinking water (50, 10, 5, and $10 \mu \mathrm{g} / \mathrm{L}$, respectively) [52] and the risk screening value for agricultural soil (250, 240, 0.8, and $170 \mathrm{mg} / \mathrm{kg}$, respectively) [53].

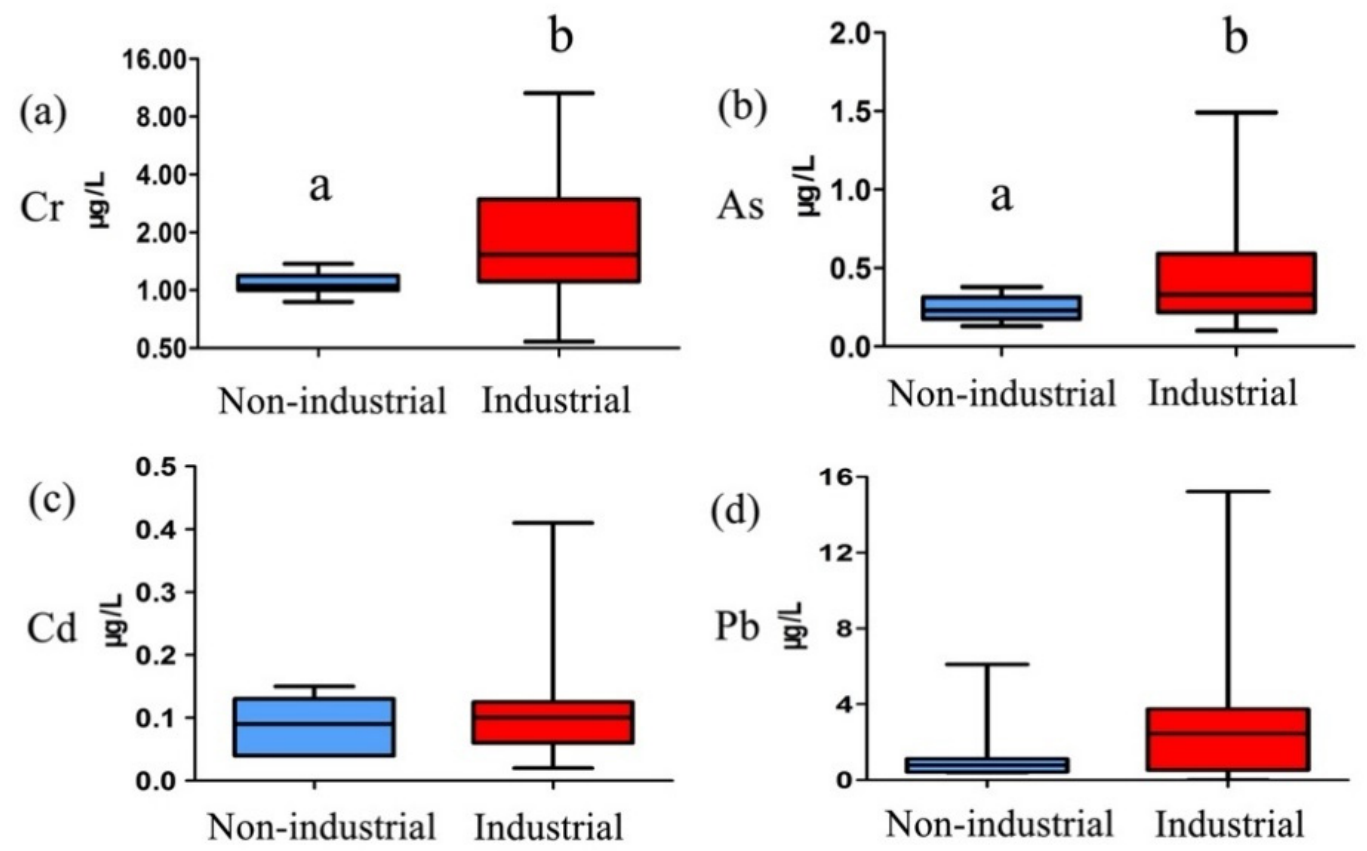

Figure 1. Comparison of heavy metal concentrations in raw milk from non-industrial and industrial areas. (a) Comparsion of $\mathrm{Cr}$ concentrations in raw milk form non-industrial and industrial areas; (b) Comparsion of As concentrations in raw milk form non-industrial and industrial areas; (c) Comparsion of $\mathrm{Cd}$ concentrations in raw milk form non-industrial and industrial areas; (d) Comparsion of $\mathrm{Cd}$ concentrations in raw milk form non-industrial and industrial areas. Superscript lower-case letters $(a, b)$ different in the same subfigures indicate significant differences $(p<0.05)$.

\subsection{The Relationships among Heavy Metals in Milk, Silage, Water, and Soil}

Previous studies have found that heavy metals in milk are related to the environmental conditions. Heavy metal pollution in the environment can contaminate milk through feed and water. The relationships between heavy metals in milk and silage, water, and soil were shown in Table 4.

Table 3. Heavy metal levels in silage, water, and soil from industrial and non-industrial areas.

\begin{tabular}{|c|c|c|c|c|}
\hline Samples & Heavy Metals & Non-Industrial & Industrial & Maximum Level \\
\hline \multirow{4}{*}{ Silage $(\mathrm{mg} / \mathrm{kg})$} & $\mathrm{Cr}$ & $1.05-1.66$ & $1.57-4.84$ & 5 \\
\hline & As & $0.05-0.11$ & $0.06-0.29$ & 2 \\
\hline & $\mathrm{Cd}$ & $0.02-0.03$ & $0.01-0.09$ & 1 \\
\hline & $\mathrm{Pb}$ & $0.16-0.22$ & $0.26-1.17$ & 30 \\
\hline \multirow{4}{*}{ Water $(\mu \mathrm{g} / \mathrm{L})$} & $\mathrm{Cr}$ & $0.07-0.38$ & ND-4.93 & 50 \\
\hline & As & $0.30-0.47$ & $0.15-2.80$ & 10 \\
\hline & $\mathrm{Cd}$ & $0.001-0.005$ & ND-0.040 & 5 \\
\hline & $\mathrm{Pb}$ & $0.09-0.15$ & $0.01-0.10$ & 10 \\
\hline \multirow{4}{*}{ Soil (mg/kg) } & $\mathrm{Cr}$ & 59-133 & $42-218$ & $250^{\mathrm{a}}$ \\
\hline & As & $5.48-10.20$ & $3.73-17.30$ & $240^{\mathrm{a}}$ \\
\hline & $\mathrm{Cd}$ & $0.09-0.10$ & $0.06-0.27$ & $0.8^{\mathrm{a}}$ \\
\hline & $\mathrm{Pb}$ & $24-29$ & $21-42$ & $170^{\mathrm{a}}$ \\
\hline
\end{tabular}


Table 4. Relationships between heavy metals in milk, silage, water, and soil.

\begin{tabular}{lllll}
\hline Samples & Cr & As & Cd & Pb \\
\hline Milk-silage & $0.626^{* *}$ & 0.326 & $0.676^{* *}$ & 0.194 \\
Milk-water & 0.041 & $0.637^{* *}$ & $0.119^{*}$ & 0.046 \\
Milk-soil & 0.344 & -0.112 & $0.557^{*}$ & 0.327 \\
Silage-water & 0.076 & $0.556^{*}$ & $0.444^{*}$ & 0.424 \\
Silage-soil & $0.604^{* *}$ & 0.180 & $0.739^{* *}$ & $0.654^{* *}$ \\
Water-soil & -0.045 & 0.113 & $0.237^{*}$ & 0.341 \\
\hline
\end{tabular}

Note: ${ }^{*} p<0.05,{ }^{* *} p<0.01$.

A strong correlation between the $\mathrm{Cr}(\mathrm{r}=0.555)$ and $\mathrm{Cd}(\mathrm{r}=0.709)$ concentrations in milk and forage was reported previously [54]. In the present study, the $\mathrm{Cr}$ levels in milk and silage were moderately positively correlated $(r=0.626)$; however, the $\mathrm{Cr}$ concentrations in milk had almost no correlation with those in drinking water $(\mathrm{r}=0.041)$, and a weak negative correlation with the soil concentration $(\mathrm{r}=0.344)$. The correlation coefficient between soil and milk $\mathrm{Cr}$ was previously reported to be 0.0007 , while for the relationship between the forage and milk concentrations it was 0.068 [55]. The As concentrations in milk and water were moderately positively correlated $(\mathrm{r}=0.637)$, while the milk concentrations were weakly positively correlated with silage concentrations $(r=0.326)$. The As level between milk and soil displayed a weak negative correlation $(r=-0.112)$. In a previous study, a positive correlation was observed between the As concentrations in milk and the drinking water provided for cattle on farms, with Pearson correlation coefficients in the range of $0.926-0.974$ [56]. The As concentrations in milk and water were weakly positively correlated $(\mathrm{r}=0.37)$, but had almost no correlation with the soil concentration $(\mathrm{r}=-0.03)$ [15].

The milk Cd concentration was moderately positively correlated with the silage $(r=0.676)$ and soil $(r=0.557)$ concentrations. A weakly positive correlation was observed between the $\mathrm{Cd}$ concentrations in milk and water samples $(\mathrm{r}=0.119)$. Fozia Batool et al. [54] investigated the possible pathways by which $\mathrm{Cd}$ was transferred to milk. The cows' fodder and the soil on which the fodder was grown were analyzed. There was a strong correlation for $\mathrm{Cd}(\mathrm{r}=0.709)$. The $\mathrm{Pb}$ concentration in milk had weak positive correlations with the concentrations in silage $(r=0.194)$ and soil $(r=0.327)$, but almost no correlation $(r=0.046)$ with the concentration in water in the present study. Similarly, a weak correlation for $\mathrm{Pb}$ was found in the same media by Fozia Batool et al. [54]. Zhou et al. [15] investigated the relationships between $\mathrm{Cd}$ and $\mathrm{Pb}$ in milk samples and the heavy metal concentrations in silage, water, and soil. A moderate positive correlation between the milk and soil concentrations was found for $\mathrm{Cd}(\mathrm{r}=0.65)$; however, there was a negative correlation between the milk and water concentrations $(\mathrm{r}=-0.75)$.

The $\mathrm{Cr}$ concentrations in silage were moderately positively correlated with soil concentrations $(r=0.556)$, and the As concentrations in silage were moderately positively correlated with water concentrations $(\mathrm{r}=0.556)$. The $\mathrm{Cd}$ and $\mathrm{Pb}$ concentrations in silage were moderately positively correlated with soil concentrations $(r=0.739, r=0.654)$ and weakly positively correlated with water concentrations $(r=0.444, r=0.424)$.

Based on the relationships among the heavy metals in milk, silage, water, and soil, it was determined that $\mathrm{Cr}$ was mainly transferred through the soil-silage-milk pathway, As was mainly transferred through the water-silage-milk or water-milk pathways, and $\mathrm{Cd}$ were mainly transferred through the soil (water)-silage-milk pathway in the present study. $\mathrm{Pb}$ in raw milk may come primarily from other feed materials.

\subsection{Exposure Assessment for $\mathrm{Cr}, \mathrm{As}, \mathrm{Cd}$, and $\mathrm{Pb}$ from Milk Consumption}

Dietary exposure is an effective method to assess food pollutants and to determine the potential health risks [57]. The EDI values of $\mathrm{Cr}, \mathrm{As}, \mathrm{Cd}$, and $\mathrm{Pb}$ were calculated for people of various ages (3-69 years), as shown in Table $\mathrm{S} 1$. The $\mathrm{Cr}$, As, $\mathrm{Cd}$, and $\mathrm{Pb}$ results for women and men were $0.0120-0.0758,0.0022-0.0138,0.0005-0.0035$, and $0.0151-0.0959 \mu \mathrm{g} / \mathrm{kg} / \mathrm{day}$ 
and $0.0101-0.0726,0.0018-0.0132,0.005-0.0033$, and $0.0128-0.0919 \mu \mathrm{g} / \mathrm{kg} /$ day, respectively. The EDI values for these metals were lower than the RfD values of $\mathrm{Cr}, \mathrm{As}, \mathrm{Cd}$, and $\mathrm{Pb}$ (3.0, $0.3,1$, and $4 \mu \mathrm{g} / \mathrm{kg} /$ day, respectively).

The tolerable daily intake (TDI) for oral $\mathrm{Cr}$ (VI) exposure of $0.9 \mu \mathrm{g} / \mathrm{kg} \mathrm{BW} / \mathrm{d}$ was established by the International Programme on Chemical Safety (ICPS) [58]. In 2010, a provisional tolerable monthly intake (PTMI) of $25 \mu \mathrm{g} / \mathrm{kg} \mathrm{BW}$ (equivalent $0.83 \mu \mathrm{g} / \mathrm{kg} \mathrm{BW} / \mathrm{d}$ for PTDI) for Cd was established by the Joint FAO-WHO Expert Committee Report on Food Additives (JEFCA) [59]. Due to the tolerable weekly intake of inorganic As [59] and $\mathrm{Pb}$ [59] being withdrawn by JECFA, only the $\mathrm{Cr}$ and $\mathrm{Cd}$ exposure values were compared with the TDI and PTDI, respectively (Figure 2). The EDI value of $\mathrm{Cr}$ for milk samples was far below the TDI $(0.9 \mu \mathrm{g} / \mathrm{kg}$ BW). The EDI value of Cd was below $0.83 \mu \mathrm{g} / \mathrm{kg}$ BW $/ \mathrm{d}$ for people aged 3 to 69 , indicating that there was no health risk associated with the $\mathrm{Cr}$ and $\mathrm{Cd}$ intake from milk consumption.

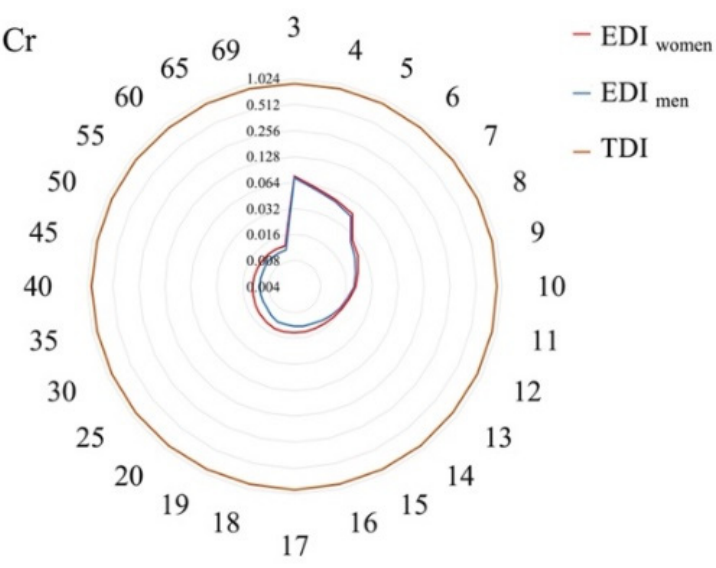

(a)

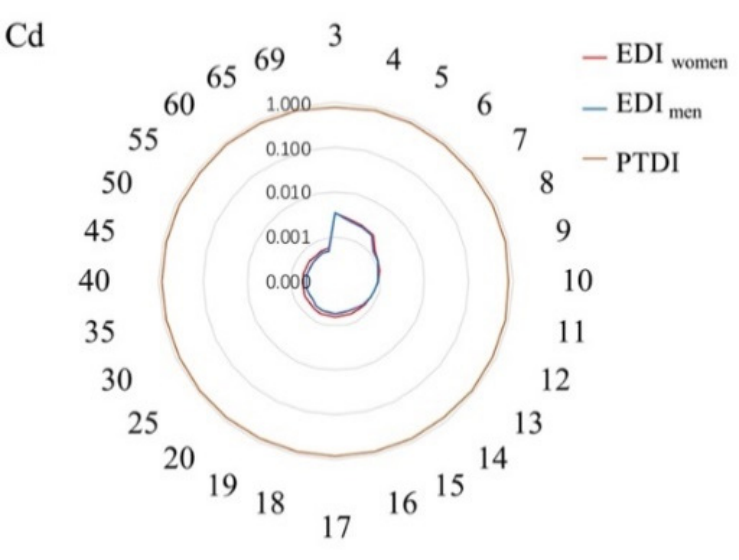

(b)

Figure 2. Comparison of the $\mathrm{Cr}$ and $\mathrm{Cd}$ exposure values ( $\mu \mathrm{g} / \mathrm{kg} /$ day) with TDI and PTDI for people aged 3 to 69 years. (a) Comparison of the Cr exposure values ( $\mu \mathrm{g} / \mathrm{kg} /$ day) with TDI for people aged 3 to 69 years; (b) Comparison of the Cd exposure values ( $\mu \mathrm{g} / \mathrm{kg} /$ day) with PTDI for people aged 3 to 69 years.

Due to the absence of an $\mathrm{As}$ and $\mathrm{Pb} \mathrm{PTWI}$ value, a non-carcinogenic risk assessment model was used to evaluate the potential risk of these heavy metals through milk for the local residents. The THQ for $\mathrm{Cr}, \mathrm{As}, \mathrm{Cd}$, and $\mathrm{Pb}$ was based on their mean concentrations in industrial areas [21].

The values of THQ and the HI for milk ingestion by local residents are summarized in Figure 3. There was an inverse relationship between the THQ values of $\mathrm{Cr}, \mathrm{As}, \mathrm{Cd}$, and $\mathrm{Pb}$ with the age of exposure. The THQ values followed a descending order of $\mathrm{As}, \mathrm{Pb}, \mathrm{Cr}$, and $\mathrm{Cd}$. The contributions of As, $\mathrm{Cr}, \mathrm{Pb}$, and $\mathrm{Cd}$ to the total THQ were $46.64 \%, 25.54 \%, 24.30 \%$, and $3.52 \%$, respectively. As shown from the data, the THQ values never exceeded the HI threshold of 1 .

The greatest risk was presented to young children due them having the lowest BW and largest milk intake of the population groups studied. On a BW basis, children could have an exposure more than twice as high as adults [59]. In terms of their THQ, men had a lower risk than women of the same age. For the HI value, As made the largest contribution, followed by $\mathrm{Pb}, \mathrm{Cr}$, and $\mathrm{Cd}$. Previous research has shown that As had the largest THQ value among the four metals investigated $[9,18,60]$, which was supported by the results of the present study. The HI values for people aged 3 to 69 years were in the range of 0.0145-0.0967, i.e., far less than the threshold of 1 . This indicates that the exposure level of these heavy metals through milk consumption will not cause adverse effects over a lifetime. It should be recognized that milk is not the single food item consumed by humans. Milk and dairy products represent only a small proportion (16.5-24.5\%) of the total mass of food 
consumed per day in China [21]. The non-carcinogenic risk presented by heavy metals could be higher when other foods are considered.

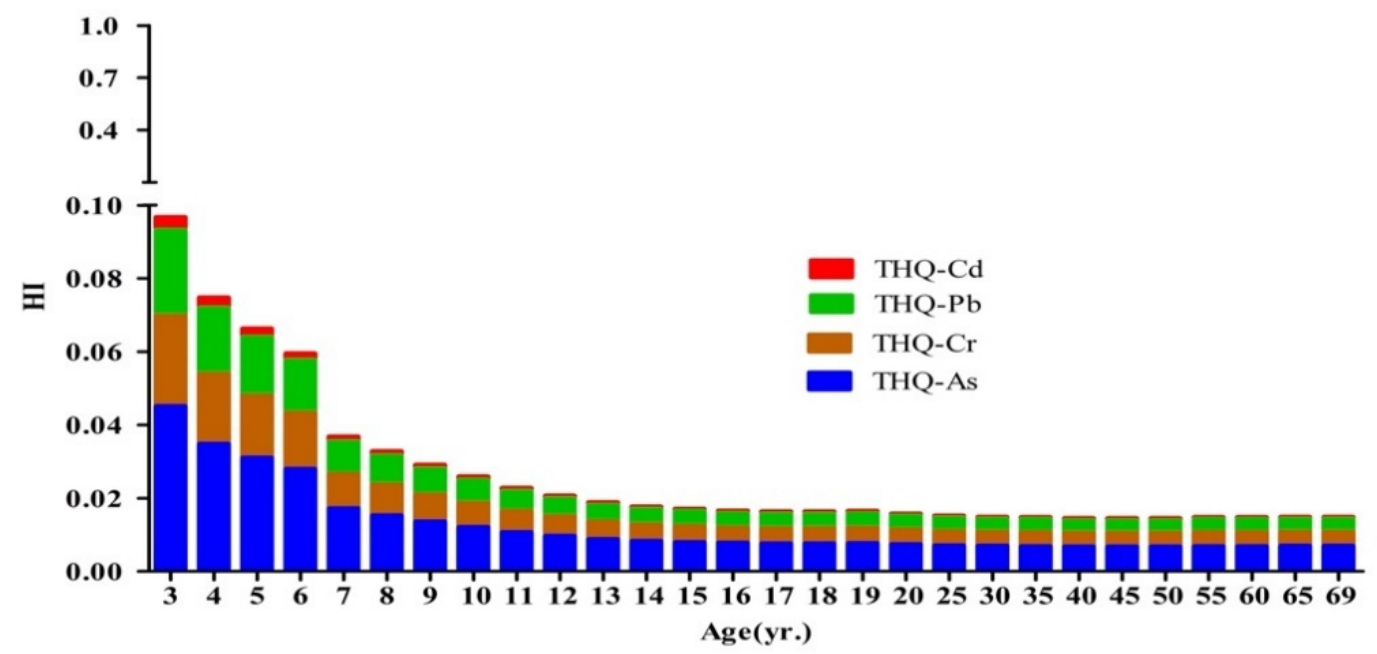

Figure 3. Target hazard quotient (THQ) and hazard index (HI) for four heavy metals exposure following milk consumption for individuals from 3 to 69 years of age.

\section{Conclusions}

The $\mathrm{Cr}$ and As levels in milk from cows reared in industrial areas were significantly higher than the levels from non-industrial areas. Chromium was mainly transferred through the soil-silage-milk pathway, As was mainly transferred through the water-milk or water-silage-milk pathways, and Cd was mainly transferred through the soil (water)silage-milk pathway. Children were at higher risk than adults.

Supplementary Materials: The following are available online at https:/ / www.mdpi.com/article/10 $.3390 /$ toxics9120320/s1, Table S1: The EDI values of Cr, As, Cd, and Pb following milk consumption by people of different ages.

Author Contributions: Conceptualization, N.Z. and J.W.; methodology, C.S., X.Q. and L.H.; software, Y.G.; validation, C.S., X.Z. and X.Q.; formal analysis, Y.G.; investigation, C.S., S.H. and X.Y.; data curation, Y.G.; writing—original draft preparation, C.S. and X.Z.; writing-review and editing, C.S. and Y.G.; visualization, L.H.; supervision, N.Z.; project administration, N.Z.; funding acquisition, N.Z. and J.W. All authors have read and agreed to the published version of the manuscript.

Funding: This research was funded by the Risk Assessment of Environmental Pollutants in Raw Milk project (GJFP2019026), the Agricultural Science and Technology Innovation Program (ASTIP-IAS12), and Modern Agro-Industry Technology Research System of the PR China (CARS-36).

Institutional Review Board Statement: The ethics committee of the Chinese Academy of Agricultural Sciences approved the study procedures (Ethics Approval No. IAS-2019-79).

Informed Consent Statement: Not applicable.

Data Availability Statement: Data is contained within the article or supplementary material.

Conflicts of Interest: The authors declare no conflict of interest.

\section{References}

1. Kwon, J.C.; Nejad, Z.D.; Jung, M.C. Arsenic and heavy metals in paddy soil and polished rice contaminated by mining activities in Korea. Catena 2017, 148, 92-100. [CrossRef]

2. González-Montaña, J.R.; Senís, E.; Gutiérrez, A.; Prieto, F. Cadmium and lead in bovine milk in the mining area of the Caudal River (Spain). Environ. Monit. Assess. 2012, 184, 4029-4034. [CrossRef]

3. Rahimi, E. Lead and cadmium concentrations in goat, cow, sheep, and buffalo milks from different regions of Iran. Food Chem. 2013, 136, 389-391. [CrossRef] 
4. Norouzirad, R.; González-Montaña, J.R.; Martínez-Pastor, F.; Hosseini, H.; Shahrouzian, A.; Khabazkhoob, M.; Ali Malayeri, F.; Moallem Bandani, H.; Paknejad, M.; Foroughi-nia, B.; et al. Lead and cadmium levels in raw bovine milk and dietary risk assessment in areas near petroleum extraction industries. Sci. Total Environ. 2018, 635, 308-314. [CrossRef] [PubMed]

5. Perween, R. Factors involving in fluctuation of trace metals concentrations in bovine milk. Pak. J. Pharm. Sci. 2015, 28, 1033-1038. [PubMed]

6. European Food Safety Authority. Scientific Opinion on Lead in Food. Eur. Food Saf. Auth. 2010, 8, 1-145. [CrossRef]

7. Panel, E.; Chain, F. Scientific Opinion on Arsenic in Food. EFSA J. 2009, 7, 1351. [CrossRef]

8. European Food Safety Authority. Cadmium dietary exposure in the European population. EFSA J. 2012, 10, 1-37. [CrossRef]

9. Su, C.; Liu, H.; Qu, X.; Zhou, X.; Gao, Y.; Yang, H.; Zheng, N.; Wang, J. Heavy Metals in Raw Milk and Dietary Exposure Assessment in the Vicinity of Leather-Processing Plants. Biol. Trace Elem. Res. 2020, 199, 3303-3311. [CrossRef]

10. World Health Organization. IARC Monographs on the Identification of Carcinnogenic Hazards to Humans. Agents Classif. IARC Monogr. 2020, 1-127.

11. Agency for Toxic Substances and Disease Registry. The ATSDR 2019 Substance Priority List; Agency for Toxic Substances and Disease Registry: Atlanta, GA, USA, 2020. Available online: https:/ /www.atsdr.cdc.gov/spl/ (accessed on 13 November 2021).

12. Patra, R.C.; Swarup, D.; Naresh, R.; Kumar, P.; Shekhar, P.; Ranjan, R. Cadmium level in blood and milk from animals reared around different polluting sources in India. Bull. Environ. Contam. Toxicol. 2005, 74, 1092-1097. [CrossRef]

13. Patra, R.C.; Swarup, D.; Kumar, P.; Nandi, D.; Naresh, R.; Ali, S.L. Milk trace elements in lactating cows environmentally exposed to higher level of lead and cadmium around different industrial units. Sci. Total Environ. 2008, 404, 36-43. [CrossRef] [PubMed]

14. National Health and Family Planning Commission; National Medical Products Administration of China National food safety standard-Limits of contaminants in food; GB 2762-2017. 2017. Available online: https://cfsa.net.cn/Standard.aspx (accessed on 13 November 2021).

15. Zhou, X.; Zheng, N.; Su, C.; Wang, J.; Soyeurt, H. Relationships between Pb, As, Cr, and Cd in individual cows' milk and milk composition and heavy metal contents in water, silage, and soil. Environ. Pollut. 2019, 255, 113322. [CrossRef] [PubMed]

16. Boudebbouz, A.; Boudalia, S.; Bousbia, A.; Habila, S.; Boussadia, M.I.; Gueroui, Y. Heavy metals levels in raw cow milk and health risk assessment across the globe: A systematic review. Sci. Total Environ. 2021, 751, 141830. [CrossRef] [PubMed]

17. Zhou, X.; Qu, X.; Zheng, N.; Su, C.; Wang, J.; Soyeurt, H. Large scale study of the within and between spatial variability of lead, arsenic, and cadmium contamination of cow milk in China. Sci. Total Environ. 2019, 650, 3054-3061. [CrossRef] [PubMed]

18. Castro-González, N.P.; Calderón-Sánchez, F.; Pérez-Sato, M.; Soní-Guillermo, E.; Reyes-Cervantes, E. Health risk due to chronic heavy metal consumption via cow's milk produced in Puebla, Mexico, in irrigated wastewater areas. Food Addit. Contam. Part B Surveill. 2019, 12, 38-44. [CrossRef]

19. Qu, X.Y.; Zheng, N.; Zhou, X.W.; Li, S.L.; Wang, J.Q.; Zhang, W.J. Analysis and Risk Assessment of Seven Toxic Element Residues in Raw Bovine Milk in China. Biol. Trace Elem. Res. 2018, 183, 92-101. [CrossRef]

20. Zhou, X.; Qu, X.; Zhao, S.; Wang, J.; Li, S.; Zheng, N. Analysis of 22 Elements in Milk, Feed, and Water of Dairy Cow, Goat, and Buffalo from Different Regions of China. Biol. Trace Elem. Res. 2017, 176, 120-129. [CrossRef]

21. Chinese Society of Nutrition. Chinese Dietary Guidelines 2016; People's Medical Publishing House: Beijing, China, 2016.

22. General Adminastration of Sport of China National health monitoring bulletin of China in 2014. 2015. Available online: http:/ / www.sport.gov.cn/n16/n1077/n1422/7331093.html (accessed on 13 November 2021).

23. Iwegbue, C.M.A.; Nwozo, S.O.; Overah, L.C.; Nwajei, G.E. Survey of trace element composition of commercial infant formulas in the nigerian market. Food Addit. Contam. Part B Surveill. 2010, 3, 163-171. [CrossRef] [PubMed]

24. United States Environmental Protection Agency. Risk Assessment Guidance for Superfund: Volume I: Human Health Evaluation Manual (Part A). 1989. Available online: https: / www.epa.gov (accessed on 13 November 2021).

25. United States Environmental Protection Agency. Chemical Assessment Summary Arsenic, Inorganic. 1991. Available online: https: / / www.epa.gov (accessed on 13 November 2021).

26. United States Environmental Protection Agency. Chemical Assessment Summary Chromium (VI). 1998. Available online: https: / / www.epa.gov (accessed on 13 November 2021).

27. United States Environmental Protection Agency. Reference Dose (RfD): Description and Use in Health Risk Assessments. 2012. Available online: https:/ / www.epa.gov (accessed on 13 November 2021).

28. Khan, N.; Jeong, I.S.; Hwang, I.M.; Kim, J.S.; Choi, S.H.; Nho, E.Y.; Choi, J.Y.; Park, K.S.; Kim, K.S. Analysis of minor and trace elements in milk and yogurts by inductively coupled plasma-mass spectrometry (ICP-MS). Food Chem. 2014, 147, 220-224 [CrossRef]

29. Khan, K.; Khan, H.; Lu, Y.; Ihsanullah, I.; Nawab, J.; Khan, S.; Shah, N.S.; Shamshad, I.; Maryam, A. Evaluation of toxicological risk of foodstuffs contaminated with heavy metals in Swat, Pakistan. Ecotoxicol. Environ. Saf. 2014, 108, 224-232. [CrossRef] [PubMed]

30. Singh, R.; Gautam, N.; Mishra, A.; Gupta, R. Heavy metals and living systems: An overview. Indian J. Pharmacol. 2011, 43, 246-253. [CrossRef] [PubMed]

31. Codex Alimentarius Commission. General Standard for Contaminants and Toxins in Food and Feed; CXS193-1995 Amended in 2019. 2019, 1-66. Available online: https:/ / www.iso.org/organization/8831.html (accessed on 13 November 2021).

32. Simsek, O.; Gültekin, R.; Öksüz, O.; Kurultay, S. The effect of environmental pollution on the heavy metal content of raw milk. Nahrung Food 2000, 44, 360-363. [CrossRef] 
33. Cadar, O.; Miclean, M.; Cadar, S.; Tanaselia, C.; Senila, L.; Senila, M. Assessment of Heavy Metals in Cows Milk in Rodnei Mountains Area, Romania. Environ. Eng. Manag. J. 2018, 14, 2523-2528. [CrossRef]

34. Sola-Larrañaga, C.; Navarro-Blasco, I. Chemometric analysis of minerals and trace elements in raw cow milk from the community of Navarra, Spain. Food Chem. 2009, 112, 189-196. [CrossRef]

35. Muhib, I.; Alamgir, M.; Chowdhury, Z.; Easha, N.J.; Rahman, M. Investigation of heavy metal contents in Cow milk samples from area of Dhaka, Bangladesh. Int. J. Food. Contam. 2016, 3, 16. [CrossRef]

36. Koyuncu, M.; Alwazeer, D. Determination of trace elements, heavy metals, and antimony in polyethylene terephthalate-bottled local raw cow milk of Iğdır region in Turkey. Environ. Monit. Assess. 2019, 191, 666. [CrossRef] [PubMed]

37. Castro-González, N.P.; Calderón-Sánchez, F.; Castro de Jesús, J.; Moreno-Rojas, R.; Tamariz-Flores, J.V.; Pérez-Sato, M.; SoníGuillermo, E. Heavy metals in cow's milk and cheese produced in areas irrigated with waste water in Puebla, Mexico. Food Addit. Contam. Part B Surveill. 2018, 11, 33-36. [CrossRef]

38. Erdogan, S.; Celik, S.; Erdogan, Z. Comparison of Selected Toxic Elements in Cow Serum and Milk Samples from Industrial and Rural Regions. Bull. Environ. Contam. Toxicol. 2004, 72, 931-936. [CrossRef]

39. Najarnezhad, V.; Akbarabadi, M. Heavy metals in raw cow and ewe milk from north-east Iran. Food Addit. Contam. Part B Surveill. 2013, 6, 158-162. [CrossRef]

40. Sobhanardakani, S. Human health risk assessment of $\mathrm{Cd}, \mathrm{Cu}, \mathrm{Pb}$ and $\mathrm{Zn}$ through consumption of raw and pasteurized cow's milk. Iran J. Public Health 2018, 47, 1172-1180.

41. Meshref, A.M.S.; Moselhy, W.A.; Hassan, N.E.H.Y. Heavy metals and trace elements levels in milk and milk products. J. Food Meas. Charact. 2014, 8, 381-388. [CrossRef]

42. Chirinos-Peinado, D.M.; Castro-Bedriñana, J.I. Lead and cadmium blood levels and transfer to milk in cattle reared in a mining area. Heliyon 2020, 6, e03579. [CrossRef]

43. Safaei, P.; Seilani, F.; Eslami, F.; Sajedi, S.R.; Mohajer, A. Determination of essential nutrients and heavy metal content of raw cow's milk from East Azerbaijan province, Iran. Int J. Environ. Anal. Chem. 2021, 101, 2368-2378. [CrossRef]

44. Ismail, A.; Riaz, M.; Akhtar, S.; Ismail, T.; Ahmad, Z.; Hashmi, M.S. Estimated daily intake and health risk of heavy metals by consumption of milk. Food Addit. Contam. Part B Surveill. 2015, 8, 260-265. [CrossRef]

45. Rubio, M.R.; Sigrist, M.E.; Encinas, T.; Baroni, E.E.; Coronel, J.E.; Boggio, J.C.; Beldomenico, H.R. Cadmium and lead levels in cow's milk from a milking region in Santa Fe, Argentine. Bull Environ. Contam. Toxicol. 1998, 60, 164-167. [CrossRef] [PubMed]

46. Bilandžić, N.; Sedak, M.; Čalopek, B.; Luburić, D.D.B.; Solomun Kolanović, B.; Varenina, I.; Dokić, M.; Kmetič, I.; Murati, T. Lead Concentrations in Raw Cow and Goat Milk Collected in Rural Areas of Croatia from 2010 to 2014. Bull. Environ. Contam. Toxicol. 2016, 96, 645-649. [CrossRef]

47. Arianejad, M.; Alizadeh, M.; Bahrami, A.; Arefhoseini, S.R. Levels of Some Heavy Metals in Raw Cow's Milk from Selected Milk Production Sites in Iran: Is There any Health Concern? Health Promot. Perspect. 2015, 5, 176-182. [CrossRef] [PubMed]

48. Swarup, D.; Patra, R.C.; Naresh, R.; Kumar, P.; Shekhar, P. Blood lead levels in lactating cows reared around polluted localities; Transfer of lead into milk. Sci. Total Environ. 2005, 349, 67-71. [CrossRef] [PubMed]

49. Singh, A.; Sharma, R.K.; Agrawal, M.; Marshall, F.M. Health risk assessment of heavy metals via dietary intake of foodstuffs from the wastewater irrigated site of a dry tropical area of India. Food Chem. Toxicol. 2010, 48, 611-619. [CrossRef] [PubMed]

50. Bakary, I.; Yao, K.M.; Etchian, O.A.; Soro, M.B.; Trokourey, A.; Bokra, Y. Zinc, copper, cadmium, and lead concentrations in water, sediment, and Anadara senilis in a tropical estuary. Environ. Monit. Assess. 2015, 187, 1-11. [CrossRef] [PubMed]

51. State Administration for Market Regulation (SAMR); Standardization administration (SA) Hygienical standard for feeds; GB 13078-2017. 2017. Available online: http:/ / openstd.samr.gov.cn/bzgk/gb/index (accessed on 13 November 2021).

52. Ministry of Health of the People's Republic of China, Standardization Administration. Standards for Drinking Water Quality; GB 5749-2006. 2006. Available online: https:/ / cfsa.net.cn/Standard.aspx (accessed on 13 November 2021).

53. Ministry of Ecology and Environment (MEE) of China Soil environmental quality Risk Control Standard for Soil Contamination of Agricultural Land; GB 15618-2018. 2018. Available online: http:/ /www.mee.gov.cn/ywgz/fgbz/bz/bzwb/trhj/201807/t201 80703_446029.shtml (accessed on 13 November 2021).

54. Batool, F.; Iqbal, S.; Tariq, M.I.; Akbar, J.; Noreen, S.; Danish, M.; Chan, K.W. MILK: Carrier of heavy metals from crops through ruminant body to human beings. J. Chem. Soc. Pak. 2016, 38, 39-42.

55. Khan, Z.I.; Ahmad, K.; Raza, N.; Al-Qurainy, F.; Ashraf, M.; Hussain, A. Assessment of chromium concentrations in soil-plantanimal Continuum: Possible risk for grazing cattle. Pak. J. Bot. 2010, 42, 3409-3414.

56. Kazi, T.G.; Brahman, K.D.; Afridi, H.I.; Arain, M.B.; Talpur, F.N.; Akhtar, A. The effects of arsenic contaminated drinking water of livestock on its total levels in milk samples of different cattle: Risk assessment in children. Chemosphere 2016, 165, 427-433. [CrossRef]

57. United States Environmental Protection Agency. Chemical Assessment Summary Lead. 2004. Available online: https://www. epa.gov (accessed on 13 November 2021).

58. The International Programme on Chemical Safety. Principles and methods for the risk assessment of chemicals in food. International Programme on Chemical Safety. Environ. Health Criteria 2009, 240, 1-34. 
59. Food and Agriculture Organization of the United Nations; World Health Organization; Joint Expert Committee on Food Additives. Safety evaluation of certain contaminants in food: Arsenic. In Proceedings of the 72nd Meeting of the Joint FAO/WHO Expert Committee on Food Additives (JECFA), Geneva, Switzerland, 16-24 June 2009; World Health Organization: Geneva Switzerland, 2011.

60. Castro Gonzalez, N.P.; Moreno-Rojas, R.; Calderón Sánchez, F.; Moreno Ortega, A.; Juarez Meneses, M. Assessment risk to children's health due to consumption of cow's milk in polluted areas in Puebla and Tlaxcala, Mexico. Food Addit. Contam. Part B Surveill. 2017, 10, 200-207. [CrossRef] [PubMed] 